\title{
The Decolonisation of Children's Rights and the Colonial Contours of the Convention on the Rights of the Child
}

\author{
Elizabeth A. Faulkner \\ Wilberforce Institute, University of Hull, Hull, UK \\ elizabeth.a.faulkner@outlook.com \\ Conrad Nyamutata \\ Leicester De Montfort Law School, De Montfort University, Leicester, UK \\ conrad.nyamutata@dmu.ac.uk
}

\begin{abstract}
The United Nations Convention on the Rights of the Child (UNCRC) 1989 has been celebrated for its universal acceptance. However, questions still arise around its provenance and representation. In particular, the Convention is deemed to enshrine Western notions of childhood upon which its rights were constructed. However, the legacy of the colonial contours of the new world order are often excluded within the context of children's rights. It has been suggested that the new imperialism brandished under the guise of "children's rights" serves as an effective tool to "beat" the Global South, deflecting from the continued Western dominance within the field of children's rights. This paper interrogates the power dynamics and colonial legacy upon which views of children are formed, centralising the multitude of issues in the arena of children's rights in the wake of what can be identified as Hokusai's wave. ${ }^{1}$
\end{abstract}

\section{Keywords}

children's rights - decolonising - colonial - international law - UNCRC

1 Katsushika Hokusai's series, "Thirty-Six Views of Mt Fuji”, features a piece known in the West as "The Great Wave" and is, according to the Guardian, 'one of the most recognisable of all art images' Katsushika Hokusai's later life to feature in British Museum Show: https://www.the guardian.com/culture/2017/jan/10/katsushika-hokusais-later-life-to-feature-in-british-mu seum-show (accessed 14 January 2020). The authors of this article have utilised the image of Mount Fuji dwarfed by the wave to illustrate the intellectual battle of children's rights.

(C) ELIZABETH A. FAULKNER AND CONRAD NYAMUTATA, 2020 | DOI:10.1163/15718182-02801009 
The United Nations Convention on the Rights of the Child (hereafter the UNCRC) 1989 entered into force on September 1990, and sought 'to provide protection for children of the full range of human rights: civil, political, economic, social and cultural' (Van Beuren, 2018: 327). The almost universal embracement of the UNCRC has frequently been heralded, with Buck noting on the day that the Convention was opened for signature (26 January 1990), that 'no less than 61 state parties signed, something of a record for an international treaty' (2014: 87). To date, the UNCRC has 196 state parties, with only the United States of America failing to ratify the Convention. ${ }^{2}$ The almost comprehensive global adoption of the UNCRC 'is frequently and justifiably celebrated by civil society' (Van Beuren, 2018: 327). This celebration of children's rights has been acknowledged, with the commemorative $30^{\text {th }}$ anniversary of the UNCRC Special Issue of The International Journal of Children's Rights. What is often neglected is whether the prima facie success of the global acceptance of the UNCRC is the end of the story of children's rights or whether the process of decolonising children's rights provides a unique lens to re-frame our approach to both the Convention and children's rights more generally.

The success story of the UNCRC can be told in different ways (Quennerstedt, Robinson and I'Anson, 2018); the 'overwhelming normative consensus affirms a shared and welcome global recognition of the rights of the child' (Kaime, 2011: 3). However, alternative perceptions that seek to explain the success of the UNCRC in terms of ratification suggest that there was ulterior impetus rather than full commitment to the children's rights agenda. For instance, it has been suggested that there was a belief that ratification would improve the international standing of the ratifying states (Pupavac, 1997). Mower Jr (1997: 14) states as follows:

It might be said that the states became parties simply to avoid the appearance of being unconcerned about children. It might also be said that they took this action because they felt that the convention contained many loopholes.

Yet others impute an intention to attract development assistance on the part of developing states. Others associate the UNCRC with a new cultural imperialism (e.g. Ibhawoh, 2007), and as a tool to "beat" the Global South.

NGOKWEY, 2004; REYNOLDS et al., 2006: 298

2 See United Nations Treaty Collection. 11. United Nations Conventions on the Rights of the Child, New York, 20 November 1989. Available at: https://treaties.un.org/Pages/ViewDetails .aspx?src=IND\&mtdsg_no=IV-11\&chapter=4\&lang=en (accessed 24 January 2020). 
The commemoration of the UNCRC presents an opportunity to examine and revaluate the epistemologies of children's rights, their representativeness and intellectual utility. In this paper, we interrogate the power dynamics and colonial legacy upon which our views of children are formed, the colonial contours of the UNCRC and the decolonisation of children's rights. References will be made to ancillary protective legal instruments on children to provide a more holistic analysis of the legal architecture underpinning children's rights. We set out an argument that scholarship on children's rights needs to be disentangled from the hegemonic Western epistemologies if it is to remain relevant. Much can be learned from scholars of transformative pedagogy who distinguish between decolonisation and decolonial theory. Decolonising learning helps us to recognise, understand, and challenge the ways in which our world is shaped by colonialism. Decolonial theory is premised on the de-emphasis of Western knowledge and modes of conception of the world. The Eurocentric history of human rights does not need to be discarded or prohibited within human rights discourse and education, but decolonial theory suggests engagement with other conceptions of rights in order to remove itself from its monologue (Barreto, 2013). It seeks to transform Western colonial epistemologies by stressing the importance of creating space for cultural, political and social memories and epistemologies from different geopolitical contexts (Richardson, 2012).

The Western-centred framing of international law and its Eurocentric origins have been subject to fierce academic debates (Anghie, 2006; Maguire, 2013); yet relatively few have sought or felt the need to challenge children's rights with the same gusto. The most pressing focus of international concern have been dominated by Western debates over issues such as child trafficking (Faulkner, 2019; Okyere, 2017), child marriage, ${ }^{3}$ child labour, ${ }^{4}$ (Balch et al., 2019) and female genital mutilation (FGM) (Kelly, B. and C. Foster, 2012). Whilst a more detailed discussion of how colonial legacies are addressed or perpetuated in these bodies of research is beyond the scope of this paper, they illustrate how our preoccupation with substance of these problems can overshadow more fundamental debates around the values and cultures that underpin research approaches as much as international legal and policy responses to such issues.

3 See Further Sustainable Development Goal 5.3, "Eliminate all harmful practices, such as child, early and forced marriage and female genital mutilation".

4 See further Sustainable Development Goal 8.7, "Take immediate and effective measures to eradicate forced labour, end modern slavery and human trafficking and secure the prohibition and elimination of the worst forms of child labour, including recruitment and use of child soldiers, and by 2025 end child labour in all its forms". 
The following section of this paper briefly discusses notions of "children and childhood" which underpin the UNCRC. Following this, part two traces the colonial contours of the UNCRC, before part three teases out the conflicts and inconsistencies in children's rights discourse. Finally, part four proposes decolonisation and ways for the recontextualisation of children's rights.

\section{International Law, Children and Childhood}

The aim of international law is to create a better society; this is no less so when it comes to children's rights law (Faulkner and Nyamutata, 2020). However, this perception of international law is not universally accepted; for some, international law is a product of European expansion through Empire and colonialism (Allain, 2012) which in turn has subordinated non-European peoples and societies to European conquest and domination (Anghie, 1996). International children's rights law, and in particular the UNCRC, is similarly criticised by many as an instrument for imposing Western ideals of the child and childhood globally.

\subsection{United Nations Conventions on the Rights of the Child (UNCRC)}

The UNCRC is the centerpiece of the international legal framework on children. Whilst it has been advocated that the 'concept of childhood ... is still not truly universal' (Humbert, 2009: 16), the UNCRC 'reflects Euro-American views' (Buck, 2014: 241). Prior to its adoption, the focus of UN bodies had been predominantly on younger children due to the lack of a globally agreed definition of childhood. ${ }^{5}$ Questions of who is a child have for many been answered through Article 1, UNCRC, which explicitly stipulates that, 'a child means every human being below the age of 18 years unless under the law applicable to the child, majority is attained earlier.' ${ }^{6}$ Age limits 'are a formal reflection of society's judgment about the evolution of children's capacities and responsibilities' (Bajpai, 2017: 2). However, from which society those judgments emerge, and what impact it has had upon children globally, is an important point within the discourse of children's rights. The idea of universal acceptance of childhood

5 The CRC Committee in recent years has focused upon the rights of older children, which culminated in the adoption of a General Comment on the implementation of the rights of the child during adolescence. See further, CRC Committee, General Comment No. 20, CRC/C/ GC/20 (6 December 2016).

6 Note that the African Union has explicitly enshrined a higher standard through the African Children's Charter (ACC), which extends childhood to 18 without any mention of the "age of majority", Article 2, ACC. 
finds justification in the swift ratification of the UNCRC, a document that has enshrined Euro-American ideals and notions of children, childhood and the politics of protection. As Peleg asserts, childhood has been framed in 'coherent and homogeneous terms and therefore the universal child was a standardized child' (2019: 12).

2.1.1

The Colonial Contours of the Convention on the Rights of the Child

A common view now exists that the UNCRC has not only imposed a universal notion of what it is to be a child; it has prescribed and embedded what the substance and scope of children's rights should be. For instance, Detrick, in her detailed and authoritative annotation of each of the substantive articles of the UNCRC, notes that the Convention 'forms a universal benchmark on the rights of the child - a benchmark against which all future claims for evolution will and must be answered' (1999: 721). For Archard, the UNCRC is a 'codification of children's rights', defining a '...recognizable canon of thought about the rights of children' (108-109). It is plausible to argue that the UNCRC is the principal driving force behind a global children's rights culture, dominating international children's policy' (Holzscheiter, 2010: 87). This assertion about the Convention, 'as a largely uncontested and legally valid norm has contributed to making the UNCRC a dominant and compelling instrument for advancing human rights for children.' (Quennerstedt, Robinson and I'Anson, 2018: 39).

The UNCRC has indeed had a major impact on the perception of childhood, children and children's rights. It has been a major catalyst in changing the social and political status of children and for achieving significant advances in law, policy and practice across the world. It has seeped into jurisprudence on children even in countries which have not incorporated the treaty into domestic law. For instance, the UK judiciary has liberally deferred to the UNCRC, in particular the "best interests" principle. ${ }^{7}$ Drawing on Article 12, UNCRC on taking into account the opinions of the child, the President of the UK Supreme Court has asserted that 'courts increasingly consider it appropriate to take account of a child's views'. ${ }^{8}$ While the US is not party to the Convention, the American courts have also referenced the Convention. ${ }^{9}$

7 See, e.g., UK cases; Z. H. (Tanzania) $v$. Secretary of State for the Home Department [2011] U KSC 4, [2011] 2 AC 166; R. (on the application of Williamson and others) $v$. Secretary of State for Education and Employment and others [2005] UKHL 15; $R$. $(A) v$. Leeds Magistrates' Court [2004] EWHC 554 (Admin) [51]; R. (Kenny) v. Leeds Magistrates' Court [2003] EWHC 2963 (Admin) $[42]$.

8 Re M. (Abduction: Zimbabwe) [2007] U KHL 55, 46.

9 See, eg., Roper v. Simmons, 543 U.S. 551 (2005); Graham v. Florida, 130 S.Ct. 2011 (2010). 
The $30^{\text {th }}$ anniversary of the UNCRC provides another moment for reflection on what has become the most celebrated treaty. Despite its global veneration as the desideratum for children's rights being demonstrably evident (Lundy, Kilkelly and Byrne, 2017), the UNCRC is vulnerable to criticism. What this paper seeks to challenge is the accepted perception that the UNCRC creates a framework of children's rights that adequately represents the world's children. Moreover, it is argued that this universal framework for monitoring States' efforts to protect and advance children's rights fails to address, and may even perpetuate, the uneven playing field aggravated by colonialism. That field of unevenness is a product of the old colonial world order, an order that has not disappeared but one that is entrenched in the construction of international law.

The aims of the UNCRC to engender the enjoyment of a broad set of rights for children globally remain unreachable because of the economic disparities between Global North and South in particular. It is almost impossible to have a universal expression of economic rights espoused in the UNCRC because of these interminable disparities.

Arguably, without addressing the "resource factor", the global enjoyment of children's rights remains a chimera. Bridging the gulf between rich and poor countries makes the "progressive realisation" of economic rights far too remote a prospect. By the time of the next anniversary of the UNCRC, it is unlikely that the goals of free education, health and so on would have been attained. Such disparities have been attributed by some countries to years of colonial rule which stagnated development throughout the Global South. ${ }^{10}$

Even though the UNCRC was drafted, adopted and ratified with the possibility of the inclusion and involvement of almost every country in the world, the colonial imprint remains, not so much in the substantive legal outcomes, but rather in the ratification process itself (Grahn-Farley, 2008). The history of ratification of the Convention shows unbalanced deployment of reservations to the UNCRC. A review of the UNCRC which adopts a specific methodology around reservations to different provisions, and objections to those reservations at the drafting stage noted thus:

It is difficult to deny the European sense of privilege when the only States parties to object to reservations are European, and twenty-one of the twenty-three parties against whom these objections were directed are postcolonial States. Moreover, no States parties objected to European

10 The term "Global South", now more preferred than "Third World", refers broadly to the regions of Latin America, Asia, Africa, and Oceania, often politically, economically and culturally marginalised. 
reservations that are equally broad in scope, such as excluding a noncitizen child from the CRC or constraining a child's right to exercise his or her culture, reservations that seem to undercut the CRC's express goal of universal coverage.

GRAHN-FARLEY, 2008: 31

Apart from the latitude provided by reservations and declarations, other reasons for the ratification of the UNCRC by African states have been offered. Some suggest that ratification of UNCRC was considered part of the neoliberal package that developing countries had to accept in order to remain part of the international community (Adu-Gyamfi and Keating, 2013). It has also been claimed that States ratified the UNCRC under the impression that it would improve their international standing (Pupavac, 1997). Further, the approach of the UNCRC, it has been argued, was 'constructive and aid-orientated' and 'children's rights have become a legitimate road to access aid'. (Reynolds, Nieuwenhuys and Hanson, 2006: 298). Many African countries thus rushed to ratify the $\mathrm{CRC}$, assuming that through ratification 'children's rights have become a legitimate road to access aid' (Reynolds et al., 2006: 298; Ngokwey, 2004).

\section{3}

\section{Children's Rights: Conflicts and Inconsistencies}

As noted earlier, the general criticism of international law is that the global infiltration of the Eurocentric model of knowledge exalted and validated specific Western practices and views (Imani, 2008: 276) resulting in the imposition of law, personal and cultural identities, and epistemologies acceptable within the Eurocentric realm. Theories of childhood by Western scholars have dominated the Western academy (Reynaert, Bouverne-de-Bie and Vandevelde; 2008; Hanson and Peleg, this issue).There is an inherent need to challenge the multiple power dynamics that exist within the field, and to centralise the legacy of colonialism within critiques of the international legal architecture that has been implemented to address the rights of children. It has been argued that the language of rights promoted a pervasive culture of liberal individualism (Hall, 2005) as opposed to the collectivist models associated with non-Western societies. Except for a few articles, ${ }^{11}$ the UNCRC focuses on an individual divorced from a social grouping (Fenton-Glynn, 2019). As Hanson and Peleg note in this volume, children's rights discourse,

11 Articles 5 and 30. 
tends to pathologize Southern families for not complying with Western views of parenthood. In other words, the focus on the individual child is in and of itself an inherent bias of the Convention, in addition to all of its other conceptual biases'.

HANSON and PELEG, this collection

The "moral crusade" to save and "individualise" children of the Third World, presumed to underpin the UNCRC also ignores the fact that traditional Africa has always respected and continues to respect a number of children's rights (Mezmur, 2008).

The Sustainable Development Goals (hereafter, SDGs) ${ }^{12}$ are at the heart of "The 2030 Agenda for Sustainable Development", providing a 'shared blueprint for peace and prosperity for people and the planet, now and into the future'. The Agenda was adopted by all of the UN Member States in $2015 .{ }^{13}$ The SDGs address a plethora of issues but a number specifically aim to eradicate harms perpetrated against children, such as SDG 5.3, which focuses upon child marriage and FGM ${ }^{14}$ and SDG 8.7, focusing upon child labour, trafficking and child soldiers. ${ }^{15}$ Despite the prima facie crusade of saving children from harmful and immoral practices, the critique of the SDGs as a potential tool for the oppression rather than the liberation of children is not to be dismissed. The adoption of the SDGs by the international community has led to a multitude of activities, inter alia, to measure, organise and implement actions to achieve these Goals. ${ }^{16}$ This activity generates knowledge production; however, as highlighted

12 The 17 (1. No Poverty, 2. Zero Hunger, 3. Good health and Well Being, 4. Quality Education, 5. Gender Equality, 6. Clean Water and Sanitation, 7. Affordable and Clean Energy, 8. Decent Work and Economic Growth, 9. Industry, Innovation and Infrastructure, 10. Reduced Inequalities, 11. Sustainable Cities and Communities, 12. Responsible Consumption and Production, 13. Climate Action, 14. Life Below Water, 15. Life on Land, 16. Peace, Justice and Strong Institutions and 17. Partnerships for the goals). Sustainable Development Goals (SDGs) encapsulate an 'urgent call for action by all countries - developed and developing - in global partnership'. See further: https://sustainabledevelopment .un.org/?menu=1300 (accessed November 2019).

13 See further: https://sustainabledevelopment.un.org/?menu=1300 (accessed 14 January 2020).

14 See Further Sustainable Development Goal 5.3, "Eliminate all harmful practices, such as child, early and forced marriage and female genital mutilation".

15 Sustainable Development Goal 8.7, "Take immediate and effective measures to eradicate forced labour, end modern slavery and human trafficking and secure the prohibition and elimination of the worst forms of child labour, including recruitment and use of child soldiers, and by 2025 end child labour in all its forms".

16 See, for example, the establishment of Alliance 8.7 which is 'an inclusive Global Partnership committed to achieving target 8.7 of the Sustainable Development Goals' with 
within this paper, this knowledge production remains predominantly western and serves to perpetuate the colonial legacy. The SDGs can be observed as a mechanism that endorse imperial approaches to the rights of children, particularly with regards to child labour and the education of children. The SDGs specifically aims to eradicate child labour by 2025 . However, what this aim neglects to recognise is how child labour is perceived as a "harm" through a western lens. Targets to eradicate child labour serve as a catalyst for the creation of and perpetuation of "unintended harms" perpetrated against children; those whom the measures seek to protect. Whilst an intricate analysis of the issue of knowledge production under the SDG agenda falls outside of the parameters of this paper, it serves as an illustrative point in relation to the new imperialism of mechanisms implemented to protect children. A new form of imperialism has sought to control and dictate the lives of children from the Global South under the guise of the SDGs, justified through a toxic cocktail of power, morality, violence and the superiority of Western perceptions.

With regards to calls to eliminate child labour, states may not necessarily lack the infrastructure and resources to eradicate it. Rather, there is concern about unintended harms caused by efforts to rescue and/or remove children from "exploitative labour" and place them into education in order to conform to Western ideals of childhood, labour and education (Adebisi, 2016) enshrined by the UNCRC. This observation is illustrated through the findings of the "Clothes, Chocolate and Children: Realising the Transparency Dividend" project, which advocated the 'need to distinguish between child labour, child workers and child 'helpers' and that initiatives should do no harm to those they seek to protect' (Balch et al., 2019: 4). The simplicity of this "rescue" narrative is not isolated to children engaged in labour upon farms; it applies to studies on child trafficking too. The international legal response to the phenomena of trafficking emerges through the UN Protocol to Prevent, Suppress and Punish the Trafficking in Persons Especially Women and Children hereafter, the Trafficking Protocol) adopted in 2000. The Trafficking Protocol conflicts with the central ethos of the UNCRC in relation to the agency of children, ${ }^{17}$ but more integrally here, the largely accepted narrative of trafficking for sexual

strategic threefold objectives, first to accelerate action, secondly to conduct research and sharing knowledge and thirdly to drive innovation and leveraging resources: www.alli ance87.org (accessed 23 January 2020).

17 The omission of the means element through Article 3 of the Trafficking Protocol 2000, is illustrative of how all those under the age of 18 are classified as lacking agency. See further, E. A. Faulkner, "The historical evolution of the international legal responses to the trafficking of children" in J. Jones and J. Winterdyk (eds.), Palgrave International Handbook of Human Trafficking (Palgrave Macmillan 2019). 
exploitation serves an effective tool to justify Kipling's "White Man's Burden" (Kempadoo, 2015; Faulkner, 2017). The anti-trafficking legal framework serves as a mechanism to prevent those perceived as vulnerable from moving, building shrewdly upon the colonial legacy of restricted immobilities (Sharma, 2017).

The African Charter on the Rights and Welfare of the Child (ACRWC) and UNCRC: Rights, Harms and Cultural Relativism**

One of the reasons for the drafting of the African Charter on the Rights and Welfare of the Child (hereafter, the ACRWC) was the sentiment that Africa had been underrepresented during the drafting of the UNCRC (Viljoen, 1991; Ankut, 2006). Additionally, it was felt that Africa needed a distinct charter for children, which reflected the specific realties of the African context. Whilst there are some similarities between the UNCRC and the ACRWC, the latter represents ideological differences in the conception of childhood and children's rights. This undercuts the UNCRC's premise as the embodiment of the "universal child". By regionalising childhood, the African variety challenges the "Eurocentric" and "universalistic" predicates of the UNCRC. Like the African Charter on Human and People's Rights (ACHPR), the ACRWC imposes certain "responsibilities" on children towards their family, society, the state and other legallyrecognised communities and the international community. Article 31 provides that:

[T] he child, subject to his age and ability, and such limitations as may be contained in the present Charter, shall have the duty to work for the cohesion of the family, to respect his parents, superiors and elders at all times and to assist them in case of need; to serve his national community by placing his physical and intellectual abilities at its service; to preserve and strengthen social and national solidarity; to preserve and strengthen African cultural values in his relations with other members of the society, in the spirit of tolerance, dialogue and consultation and to contribute to the moral well-being of society; to preserve and strengthen the independence and the integrity of his country; and to contribute to the best of his abilities at all times and at all levels, to the promotion and achievement of African Unity.

Non-Western societies are often characterised by more "collectivist" or "interdependent" cultural models not articulated in the UNCRC. Such societies often espouse communal goals more highly, such as learning to live in harmony with one another, competent participation in social events, obedience to authority 
and a cooperative and altruistic orientation (Rosenthal, 2000). Such variances in goals and expectations mediate the daily experiences of children, their interactions with the persons, objects and symbols in their immediate environment (ibid.). "Child labour" - in essence "communal work" at the home - would often, however, then be misconstrued as some form of abuse.

Researchers recognising the different conceptions of childhood discussed above have theorised such variations through the lens of "cultural relativism". As Hanson and Peleg point out, in children's rights studies, it is not so much the absence of theories, but rather reflections and discussions about the normative relevance, analytical qualities and explanatory powers of the mobilised theories (Hanson and Peleg, this issue). While in some academies cultural relativism as a "theory" is acknowledged, some have questioned its validity as an explanatory device (Karanek, 2013; Schmidt, 1955) and an impediment to the grand project of international law. Yet others have found utility in its theoretical proposition. Proponents of cultural relativism suggest it embodies many variants and, as such, cannot be spoken of as a monolithic theory (e.g. Zechenter, 1997). Critics of cultural relativism argue that it is deleterious as an intellectual proposition (e.g. Kanarek, 2013).

Cultural relativism is destructive in both theory and practice. In its theoretical denial of reason and objective reality, it sanctions the worst forms of violence and oppression in practice. This is unsurprising; a theory that adamantly denies reason and reality cannot be suitable for the latter, nor be sound according to the former (ibid.:1).

We suggest that such criticism seems intellectually self-defeating: cultural particularities are objective realities. It is difficult to argue that the UNCRC, for instance, is culturally-neutral. The relegation of cultural relativism as an embodiment of primordial instincts and a subaltern, if not, an invalid analytical lens, has inevitably generated hostility towards, for example, the so-called "cultural defence" in criminal law proceedings (Renteln, 2009: 61). In the case of children, a defence, which draws on cultural practice is often readily juxtaposed, for rebuttal, against the provisions of the UNCRC (e.g. Freeman, 2007). However, the popular disdain towards the "defence of culture" is, in essence, a denial of the objective reality of difference. As an expression of difference, it reflects the objective realities of cultural variation. Such divergences can be neither easily nor wholly dismissed nor juxtaposed against norms purporting to be universalistic.

The approaches to FGM and Female Genital Cosmetic Surgery (FGCS) in the West are illustrative. FGM is regarded to violate both women's and children's 
human rights, including their rights to health, to be free from violence, to life and physical integrity, to non-discrimination and to be free from cruel, inhuman, and degrading treatment. However, research suggests that the effects of FGM and FGCS are, in fact, not dissimilar. Kelly and Forster assert that anatomically, 'there is little to distinguish FGM from many or most of the procedures involved in FGCS. On the face of it, then, many such procedures seem prima facie unlawful...' (2012: 390). There is insufficient documentation of both the safety and effectiveness of these procedures. Potential complications can include infection, altered sensation, dyspareunia, [and] adhesions and scarring (Renganathan, Cartwright and Cardozo, 2009: 103). Where harm is concerned, "consent" is an insufficient defence. In the UK, a tattooist faced three counts based on removal of a customer's ear; removal of a customer's nipple; and splitting a customer's tongue to resemble a reptile's tongue - procedures he had performed without anaesthetic. The judge decided that consent could not provide a defence to causing actual bodily harm or wounding, unless the conduct fell into a special exception to the general rule. ${ }^{18}$

While Western doctors liberally perform "cosmetic surgery" without legal reproach, doctors who have conducted "mutilations", even under clinical conditions, have been prosecuted. In the US, Dr. Jumana Nagarwala, the lead defendant, was charged with committing female genital mutilation on under-age girls (Liao, Taghinejadi and Creighton, 2012) at a clinic Livonia in violation of federal law. ${ }^{19}$ U.S. District Judge Bernard Friedman concluded that 'as despicable as this practice may be', Congress did not have the authority to pass the 22-year-old federal law that criminalises female genital mutilation, and that FGM is for the states to regulate. In the UK, doctors have also been charged and prosecuted or struck off the medical practitioners' register for FGM even when such operations are conducted under clinical conditions. ${ }^{20}$ The discrepancies in approaches to genital alteration have triggered accusations of moral relativism on the part of the West. Moral relativism purports superiority over another culture. To date, there remains a reticence to invoke any legal proceedings against doctors for conducting FGCs. The UK House of Commons noted thus:

18 R. $v B M$ R. $v M$ [2018] EWCA Crim 56o; [2019] Q.B. 1; [2018] 3 W.L.R. 883; [2018] 3 WLUK 554; [2018] 2 Cr. App. R. 1;[2018] L.L.R. 514; [2018] Crim. L.R. 847.

19 United States v.Jumana Nagarwala et al., No. 1 7-cr-20274 (E.D. Mich. 20 November 2018).

20 See, e.g., S. Laville, "Doctor found not guilty of FGM on patient at London hospital", The Guardian UK, 4 February 2015: https://www.theguardian.com/society/2015/feb/o4/doc tor-not-guilty-fgm-dhanuson-dharmasena (accessed 24 January 2020). The doctor performed FGM on an adult.; ввС "'Genital mutilation' doctor struck off after undercover press sting", 30 May 2014: https://www.bbc.co.uk/news/uk-england-birmingham-27641431 (accessed 24 January 2010). 
Despite the Government's assurances that there is no ambiguity in the law relating to female genital cosmetic surgery, our evidence demonstrates that the police, midwives and campaigners would all like to see greater clarity on this point. We cannot tell communities in Sierra Leone and Somalia to stop a practice, which is freely permitted in Harley Street. We recommend that the Government amend the FGM Act 2003 in order to make it very clear that female genital cosmetic surgery would be a criminal offence. $^{21}$

The SDGs, which address "harmful cultural practice", do not offer any clarity on this inconsistency either. As argued earlier, activity around SDGs generates knowledge production which is principally Western-biased. The point is not necessarily the rights or wrongs of FGM but the difference in perceptions of and action for essentially similar practices. While framers of the ACRWC indeed sought the outlawry of "harmful cultural practices", 22 which would include FGM, it is fair to conclude that they did not anticipate that harmful practices would be treated differently on account of such practice being allocated a different, perhaps, appealing name elsewhere. "Mutilation" denotes a sense of "savagery" while "cosmetic" is associated with "beauty".

The ACRWC itself does not enjoy the same recognition in the academy as the UNCRC on the pretext that it merely duplicates the Convention. However, a closer examination illustrates that the ACRWC indeed 'uses the language of the convention in greater similarity but with subtle differences to reflect African contexts' (Adu-Gyamfi and Keating, 2013). However, some divergencies are more explicit. It is notable that, on child soldiery for example, the African Union has explicitly enshrined a higher standard through the ACRWC. ${ }^{23}$ Within the ACRWC instrument, childhood extends to 18 without any reference to the age of majority, ${ }^{24}$ with a specific view to prohibiting state parties '...from recruiting soldiers under the age of 18' (Van Beuren, 2018). The ACRWC is not necessarily a replication but a reflection of cultural nuances deserving of recognition in their own right. It reinforces the perception of a "child", not as an "atomised" individual, but as part of a social grouping.

It is for this reason that children in such social settings are integral to the collective, family endeavours. It has been acknowledged that "child labour" in

21 Appendix 1: Recommendations from 2015 Home Affairs Committee Report on FGM, Para. 4 .

22 Article 21, ACRWC.

23 Only regional instruments to outlaw recruitment of children under the 18 into armed forces or groups.

Article 2, ACRWC. 
such spaces is a survival strategy, which contributes to the family income (Tafere and Pankhurst, 2015). Article 32 of the UNCRC enjoins states parties to recognise the right of the child to be protected from economic exploitation and from performing any work that is likely to be hazardous or to interfere with the child's education, or to be harmful to the child's health or physical, mental, spiritual, moral or social development. As such, the UNCRC and popular scholarship have portrayed child labour and education as mutually exclusive (Akhtar and Nyamutata, 2020). However, emerging empirical scholarship is increasingly more nuanced on this correlation. Several studies highlight both benefits and risks related to child labour (Tafere and Pankhurst, 2015). Although children's work can negatively affect children's educational achievement (Woldehanna and Gebremedhin, 2015), working can, in fact, enable children to pursue education as well (Aufseeser, 2014). Many children engage in both school and work; in some cases this is not only necessary, but useful (Tafere and Pankhurst, 2015). In such contexts, education is regarded as an activity to fit around other aspects of life, especially work (Crivello, and Van der Gaag, 2016). Policy concern should thus focus on supporting children who combine working and education, rather than with abolishing children's work (Bourdillon, 2017). International human rights and Western outrage are at times devoid of such important contexts:

Contextualizing theories of human rights means showing the genealogical connection that ties the Eurocentric theory of rights to the historical setting in which it was elaborated. Unveiling the linkage to the site of emergence of knowledge weakens or destroys the legitimacy of claims to universality. The dominant theory is no longer "the" theory of human rights, but just a theory born in the background of the history of Europe and, as a consequence, has no claim to be universally compelling. The re-contextualization and contextualization of the hegemonic theory of human rights in the material conditions of modern/colonial geography and history paves the way for re-drawing and re-writing the geography and history of human rights.

BARRETO 2013: 19

International organisations are the agents through which "universal norms" of world hegemonies are expressed. The International Labour Organization (ILO), apart from its broader focus on labour concerns, has been the leading organisation in developing the protective framework on child labour. One of its earlier instruments on child labour, the ILO Minimum Age Convention (No.138), was essentially abolitionist in seeking to ban all child work below 
particular ages (Smolin, 2000). ILO's minimum-age policies reflect a paradigm that assumes that children benefit from being withdrawn or excluded from work (Bourdillon, White and Myers, 2009). The Minimum Age Convention defines child labour in terms of a minimum age of employment, and establishes that age as not less than 15 years. ${ }^{25}$ For developing countries, where the economies and educational facilities are underdeveloped, the Convention sets the minimum age of employment at $14 .{ }^{26}$ However, the arbitrary imposition of the upper limit of childhood by the Convention conflicts with African conceptions where age has no particular relevance in determining childhood or adulthood. The hierarchy of harms perpetrated against children enshrined by the ILO Convention on the Worst Forms of Child Labour (No. 182) ignores the context of work for children. The instrument serves as a tool effectively to undermine the very notion that children's work can be legitimate and positive, drawing a hierarchical framework of protection from what the West classifies as the "worst forms of child labour". The presumptions on child labour need to be revisited.

\subsection{Recontextualising Children's Rights}

The need to re-imagine children's rights has become imperative. In her reflection, Schwöbel-Patel (2013) argues that Western centres and clusters of international law teaching, in particular, are reproducing Eurocentric enlightenment ideas and presenting them as global. International law lecturers and researchers, she argues, are surrendering to certain spheres of influence and 'are furthering a cultural hegemony', first, 'because of their own education of international law, and, second, because they are disciplined to teach in this way.' (ibid:: 71). A focus on knowledge production, centres of learning and pedagogical practices becomes critical to a transformative agenda. We have proposed an approach which attempts to "decolonise" children's rights and the pedagogy of the field.

However, what does decolonisation encompass? Inevitably, the suggestion of "decolonisation" of studies generally has generated concern if not covert and overt resistance in some quarters (Stokes, 2019). The presumed prospect of the "banishment" of Derrida, Foucault, Arendt, Kant, Piaget, Sigmund and others from university library shelves or catalogues has caused some discomfort. However, such apprehension is based on a misconception of the decolonisation agenda. Tuck and Yang contest that the

25 Article 2(3).

26 Article 2(4). 
easy adoption of decolonising discourse by educational advocacy and scholarship, evidenced by the increasing number of calls to "decolonize our schools" or to use "decolonising methods" or, "decolonize student thinking” turns decolonization into a metaphor' (2012).

Scholars of transformative pedagogy distinguish between decolonisation and decolonial theory. Decolonisation encompasses a multitude of definitions (Bhambra et al., 2018), and use of the term has been fiercely contested (Tuck and Yang, 2012). The conversation about the decolonisation of the university and the curricula continues to raise questions for both knowledge production and transmission in educational institutions (Bhambra et al., 2018). Decolonisation is:

First, it is a way of thinking about the world that takes colonialism, empire and racism as its empirical and discursive objects of study; it resituates these phenomena as key shaping forces of the contemporary world, in a context where their role has been systematically effaced from view. Second, it purports to offer alternative ways of thinking about the world and alternative forms of political praxis. And yet, within these broad contours, "decolonising" remains a contested term, consisting of a heterogeneity of viewpoints, approaches, political projects and normative concerns (ibid.: 2)

Decolonial theory is premised on the de-emphasis of Western knowledge and modes of conception of the world. It seeks to transform Western colonial epistemologies by stressing the importance of creating space for cultural, political and social memories and epistemologies from different geopolitical contexts (Richardson, 2012). To be clear, a decolonising agenda does not elide the Eurocentered narrative; it recognises 'its right to exist, since it corresponds with the experience of Euro-American histories, but it does not have the right to be the narrative for the rest of the world, except in its imperial/colonial dimensions' (Mignolo 2013: 19). The process of decolonising culture, humanities and social sciences forms an intellectual and political project that emerges from the standpoint of the Third World and aims at opposing colonialism and the abuse of power (Barreto, 2013).

The commemoration of the UNCRC lends another opportunity for candid re-examination of children's rights scholarship. In this paper, we propose that the decolonisation of children's lives would recontextualize children's rights. Decolonising learning helps us resituate children's rights discourse, recognise, understand and challenge the ways in which our world is shaped by colonialism. 
Since the adoption of the UNCRC, the meanings attributed to children's rights within global academic and political arenas are largely based upon the text of the Convention (Quennerstedt, Robinson and I'Anson 2018). Historically, nonAfrican scholars have propounded theories of childhood. Greater attention needs to be paid to such scholarship on the histories that other analytical perceptions bring to the study of international law. As an analytical device, decolonial theory, while acknowledging the Eurocentric construction, attempts to recontextualize human rights law. It proposes an oppositional ideology to the coloniality of power. Such ideology is achievable by means of 'epistemological decolonization', permissive of intercultural communication and exchange of experiences in order to produce different conceptions of rationality (Quijano, 2000).

Recontextualization of children's rights would mean that dominant theories of "childhood" are born in the background of the history of Europe. As such, these have no claim to be universally compelling. Secondly, recontextualisation would focus on the knowledge production and pluralised approach to pedagogy. Such approach ultimately aims at incorporating theoretical, conceptual and analytical tools which widen the knowledge base within the legal academy. In the globalized context in which we live, a student should be fully prepared to face the social realities of law. Future international lawyers 'who are taught today will enter international legal organizations, or other legal outfits (law firms, governments) with a certain influence and a particular notion of 'how the world works' (Schwöbel-Patel, 2013: 69).

Pedagogy fixated on hegemonic epistemologies of childhood and rights requires reframing if legal scholarship on children's rights is to remain relevant in a globalised context. Such an enterprise would entail the deliberate accommodation of intellectual resources from the Global South.

An under-acknowledged analytical tool is the Third World Approaches to International Law (TWAIL). As a device for analysis of international law, TWAIL has remained a peripheral tool in the rationalisation of international law (Sunter, 2007). Yet it can be a useful tool for recontextualizing children's rights. TWAIL developed in phases: TWAIL I scholarship was concerned with the recognition of a right to development; its approaches to international human rights law were largely state-centric (Badaru, 2008). TWAIL II scholars, on other hand, are largely people-centric, as they aim to 'identify and give voice to the marginalized people within Third World states - women, workers, minorities who they believe had been generally excluded from consideration by TWAIL I scholarship'(ibid::383). Aside from these phases, the ultimate agenda of TWAIL is reforming and remaking international law (Gathii, 2019). A TWAIL perspective, 'helps one to be conscious of the oppressive potential of universality, and 
to scrutinise which aspects of human rights may be made universal and which aspects need to be re-examined' (Badaru, 2008: 383 ).

As such, TWAIL fits snugly into the agenda of decolonisation. However, the limited resources and support for researchers from the Global South to conduct and publish their work on international platforms impose serious constraints on the decolonisation agenda (Ntona and Morgera, 2018). The "hostile environment" fostered in the United Kingdom and the United States, for example, have established or emphasised restrictive barriers to scholars through denial of visas to attend conferences and lectures, in turn restricting the ability of those scholars to disseminate their research. Moreover, when funders in the Global North allocate resources to a specific project or issue, actors in the Global South have commonly been obliged to align their activities with the interests and agendas of their external funders (Bunting and Quirk, 2017: Dotteridge, 2014). The failure and difficulty of Western scholars both to access and take on board resources and perspectives from the global South sustain an ideological dominance in legal pedagogy.

We, as academics, need to challenge and constantly interrogate the inherent violence and power dynamics that shape the underlying presumptions upon which our worldviews are built. In most Western academies, the texts on and theories of international law still constitute the "essential readings" for most modules. The sources of knowledge production are thus predominantly Western, which make us 'complicit in the reproduction of the existing unequal structures...' (Schwöbel-Patel, 2013: 68). To a very little extent do Western academies draw on published research from the Global South. This is partly because researchers located in those regions are not adequately resourced to conduct that much needed work in a localized, culturally sensitive way and to share it with the rest of the world (Kronenberg, 2016). Language barriers, limited access to research tools and less developed research infrastructures all inhibit the development and dissemination of this work.

\section{4 \\ Conclusion}

The $30^{\text {th }}$ anniversary of the UNCRC is a cause to celebrate. However, it is also a point at which we need to pause and reflect critically upon what it is that we are commemorating. Are we celebrating the continuation of Western dominance over former colonies through the embodiment of children's rights? We need to continue to reflect critically on whether the imposition of rules on non-Western states through the UNCRC (for example, under the guise of the "best interests principle") perpetuates particular Westernised ideals which are 
ill-fitted (and perhaps even damaging) for children in other contexts. Relatedly, the international legal and policy framework needs to offer more nuanced guidance on important contexts in relation to child labour, education and "children on the move".

This paper has sought to utilise a decolonial lens for the analysis of children's rights and seeks to challenge both the pedgagogy and scholarship of the discourse, whilst simultaneously inviting scholars to recognise and engage with the colonial legacies that perpetuate the study of children's rights. The colonial legacy present within the discourse of children's rights needs to be challenged; from the development and implementation of the international legal framework, to the teaching of children's rights, to removing barriers to scholars from the Global South to participating within the discourse. Utilising knowledge production could serve as a mechanism to bring about the aim of decolonising the field of children's rights research. These barriers to scholars and activists manifest as Hokusai's wave, a wave that suppresses, prevents and subsequently perpetuates the dominance of imperialist approaches to children's rights knowledge and reform.

\section{References}

Adebisi, F., "Decolonising education in Africa: Implementing the right to education by re-appropriating culture and indigeneity", Northern Ireland Legal Quarterly, 2016 (67 (4)) 433-451.

Adu-Gyamfi, J. and Keating, F., "Convergence and Divergence between the UN Convention on the Rights of the Children and the African Charter on the Rights and Welfare of the Child", Sacha Journal of Human Rights 2013 (3(1)) 47-58.

Akhta, R. and Nyamutata, C., International Child Law, $4^{\text {th }}$ edn. (Routledge, forthcoming, 2020).

Allain, J., Slavery in International Law: Of Slavery and the Law of Nations (Brill, 2012).

Anghie, A., "Francisco de Vitoria and the Colonial Origins of International Law", Soc. \& Legal Stud. 1996 (5) 321.

Anghie, A., "The evolution of international law: Colonial and postcolonial realities" Third World Quarterly, Reshaping justice - International Law and the Third World, 2006 (27 (5)), 739-753.

Ankut, P., "The African Child: Linking Principle with Practice," Open SocietyInitiative of West Africa (OsIWA, 2006).

Archard, D., Children: Rights and Childhood (Routledge, 2015) 108-109.

Aufseeser, D., "Limiting spaces of informal learning among street children in Peru in Mills" in S. and Peter Kraftl, P. (ed.), Informal Education, Childhood and Youth: Geographies, Histories, Practices (Palgrave Macmillan, Basingstoke, 2014). 
Badaru, O., "Examining the Utility of Third World Approaches to International Law for International Human Rights Law" International Community Law Review 2008 (10 (4)) 379-387.

Bajpai, A., Child Rights in India: Law, Policy and Practice (Oxford India paperbacks, 2017). Balch, A., Johns, J., Vaughn, L., Currie, S., Stalford, H. and Robinson, C., "Clothes, Chocolate and Children: Realising the Transparency Dividend" (University of Liverpool, British Academy and Department for International Development, 2019).

Barreto, J., Decolonial Strategies and Dialogue in The Human Rights Field in Human Rights from a Third World Perspective: Critique, History and International Law (Cambridge Scholars Publishing Newcastle Upon Tyne, 2013).

Barreto, J., Human Rights from a Third World Perspective: Critique, History and International Law (Cambridge Scholars Publishing, 2013).

Bhambra, G., Gebrial, D. and Nişancıŏgluet, K. (2018), Decolonising the University (Pluto Press, London, 2018).

Bourdillon, M., "Ignoring the Benefits of Children's Work: Beyond Trafficking and Slavery. Open Democracy", Open Democracy (2017). Available at: https://www.opende mocracy.net/beyondslavery/michael-bourdillon/ignoring-benefits-of-children-s -work (accessed 16 January 2020).

Bourdillon, M., White, B. and Myers, W., "Re-assessing minimum-age standards for children's work", International Journal of Sociology and Social Policy 2009 (29 (3/4)) 106-117.

Buck, T., International Child Law (Routledge, 2014).

Bunting, A. and Quirk, J., Contemporary Slavery: The Rhetoric of Global Human Rights Campaigns (Cornell University Press, 2017).

Chimni, B., "Third World Approaches to International Law: A Manifesto", International Community Law Review 2006 (8) 3-27.

Crivello, G. and Van der Gaag. N., "Between hope and a hard place: Boys and young men negotiating gender, poverty and social worth in Ethiopia", Working Paper 160, (Oxford: Young Lives, 2016).

Detrick, A., Commentary on the United Nations Convention on the Rights of the Child (The Hague/Boston/London: Martinus Nijhoff Publishers, 1999).

Dotteridge, M., "Following the Money: Spending on Anti-Trafficking" Anti-Trafficking Review 2014, 3, 3-175.

Faulkner E. A., "Historical evolution of the international legal response to the trafficking of children - a critique" in The Palgrave International Handbook of Human Trafficking (Palgrave, Macmillan 2019).

Faulkner, E. A., "How the idea of 'modern slavery' is used as political click bait", 16 October 2017: https://theconversation.com/how-the-idea-of-modern-slavery-is-used-as-po litical-click-bait-84877 (last accessed 16 January 2020).

Fenton-Glynn, C. (eds), Children's Rights and Sustainable Development: Interpreting the UNCRC for Future Generations (Cambridge University Press, 2019). 
Freeman, M., Article 3: The Best Interests of the Child, (Martinus Nijhoff Publishers, 2007).

Gathii, J., "The Agenda of Third World Approaches to International Law (TWAIL)" in J. Dunoff and M. Pollack (eds.) International Legal Theory: Foundations and Frontiers, forthcoming (Cambridge University Press, 2019).

Grahn-Farley, M., "Neutral Law and Eurocentric Lawmaking: A Postcolonial Analysis of the U.N. Convention on the Rights of the Child", Brooklyn Journal of International Law 2008 (34 (1)), 1-32.

Hall, D., "Children, rights, and responsibilities", Archives of Disease in Childhood (2005) (9o (2)), 171-3.

Hanson, K. and Peleg, N., "Waiting for Children's Rights Theory”, forthcoming, The International Journal of Children's Rights (2020).

Holzscheiter, A., Children's Rights in International Politics (Palgrave Macmillan, Basingstoke, 2010).

Howard, N., Child Trafficking. Youth Mobility and the Politics of Protection (Palgrave Macmillan, 2017).

Humbert, F., The Challenge of Child Labour in International Law (Cambridge University Press, 2009).

Ibhawoh, B., Imperialism and Human Rights: Colonial Discourses of Rights and Liberties in African History (New York: SUNY Press, 2007).

Imani, N. O., "Critical Impairments to Globalizing the Western Human Rights Discourse", Societies Without Borders, (2008) (3(2)), 270-284.

Kaime, T., The Convention on the Rights of the Child. A Cultural Legitimacy Critique (Europa Law Publishing, 2011).

Kanarek, J., "Critiquing Cultural Relativism," The Intellectual Standard 2013 (2 (1)), 1-14. Kelly, B. and Foster, C., "Should female genital cosmetic surgery and genital piercing be regarded ethically and legally as female genital mutilation", BJOG: an International Journal of Obstetrics \& Gynaecology 2012, (119) 389-392.

Kempadoo, K., “The Modern-Day White (Wo)Man's Burden: Trends in Anti-Trafficking and Anti-Slavery Campaigns", Journal of Human Trafficking 2015, (1 (1)):8-20.

Kronenberg, C., "Scholarly collaboration: it's time for the global South to call the shots", The Conversation, 17 November 2016.

Liao, L., Taghinejadi, N., Creighton S., "An analysis of the content and clinical implications of online advertisements for female genital cosmetic surgery", BMJ Open 2012 $(2(6)), 1-6$.

Lundy, L., Kilkelly, U. and Byrne, B., "Incorporation of the United Nations Convention on the Rights of the Child in Law: A Comparative Review"in U. Kilkelly and L. Lundy (eds.), Children's Rights (The Library of Essays on Family Rights) (vol. 1: 223) (Routledge, 2017).

Maguire, A., "Contemporary Anti-Colonial Self-Determination Claims and the Decolonisation of International Law", Griffith Law Review 2013 (22 (1)), 238-268. 
Mezmur, B., "The African Children's Charter versus the UN Convention on the Rights of the Child: A zero-sum game?", SA Public Law (2008) 23 (1) 1-29.

Mignolo, W., "Preamble: The Historical Foundation of Modernity/Coloniality and the Emergence of Decolonial Thinking' in S. Castro-Klaren (ed.), A Companion to Latin American Literature and Culture (Wiley-Blackwell, Malden MA, 2013).

Morrow, V., "The intersections of school, work and learning: Children in Ethiopia, Andra Pradesh, India, Peru and Vietnam" in T. Abebe, et al. (eds.), Labouring and Learning. Geographies of Children and Young People (Springer, Singapore, 2015).

Morrow, V., "The intersections of school, work and learning: Children in Ethiopia, Andra Pradesh, India, Peru and Vietnam" in T. Abebe, et al. (eds.), Labouring and Learning. Geographies of Children and Young People (Springer, Singapore, 2015).

Morrow, V. and Boyden, J., "Responding to Children's Work: Evidence from the Young Lives Study in Ethiopia, India, Peru and Vietnam" Summative Report (Oxford: Young Lives, 2018).

Mower Jr, G., The Convention on the Rights of the Child: International Law Support for Children (Greenwood Press, 1997).

Ngokwey, N., "Children's Rights in the Central Africa sub-region: Poverty, Conflicts and HIV/AIDS as context", The International Journal of Children's Rights, 2004 (12(3)) $183-216$.

Ntona, M. and Morgera, E.,"Connecting SDG 14 with the other Sustainable Development Goals through marine spatial planning”, Marine Policy 2018 (93), 214-222.

Okyere, S., "'Shock and Awe': A critique of the Ghana-centric child trafficking discourse", Anti Trafficking Review, 2017 (9) 92-105.

Peleg, N., The Child's Right to Development (Cambridge University Press, 2019).

Pupavac, V., “Theories of Conflict and Children's Rights", paper presented at $2^{\text {nd }}$ Convention of the European Association for the Advancement of Social Sciences (1997).

Quennerstedt, A., Robinson, C. and I'Anson, J., "The UnCrC: The Voice of Global Consensus on Children's Rights?", Nordic Journal of Human Rights, 2018 (36 (1)), 38-54.

Quijano, A., "Coloniality of Power and Eurocentrism in Latin America", International Sociology, $200015(2), 215^{-232 .}$

Renganathan, A., Cartwright, R. and Cardozo. L., "Gynecological Cosmetic Surgery”, Expert Review of Obstetrics \& Gynecology 2009 4(2) 101-104.

Renteln, A., "The Use and Abuse of the Cultural Defence" in M. Foblets and A. Renteln (eds.), Multicultural Jurisprudence: Comparative Perspectives on the Cultural Defence (Oxford: Hart Publishing, 2009).

Reynaert, D., Bouverne-de-Bie, M., Vandevelde, S., "A Review of Children's Rights Literature since the Adoption of the United Nations Convention on the Rights of the Child", Childhood 2009 (16(4)), 518-534.

Reynolds, P., Nieuwenhuys, O. and Hanson, K., "Refractions of Children's Rights in Development Practice", Childhood 2006 (13 (3)), 291-302. 
Richardson, T. A., "Disrupting the Coloniality of Being: Toward De-colonial Ontologies in Philosophy of Education", Studies in Philosophy and Education, 2012, (31(6)), 539-551.

Rosenthal, M., "Home to early childhood service: an ecological perspective", Childrens Issues, 2000 4(1), 7-15.

Schmidt, P., "Some Criticisms of Cultural Relativism," The Journal of Philosophy 1955 (52 (25)) 780-791.

Schwöbel-Patel, C., "'I'd Like to Learn What Hegemony Means' - Teaching International Law from a Critical Angle", Recht en Methode (Law and Method), 2013. Available at SSRN: https://ssrn.com/abstract=2339303.

Sharma, N., "The New Order of Things': Immobility as protection in the regime of immigration controls", Anti-Trafficking Review, 2017, 9 Special Issue - The Lessons of History.

Smolin, D., "Strategic Choices in the International Campaign against Child Labor", $\mathrm{Hu}$ man Rights Quarterly 2000 (22 (4)), 942-987.

Stokes, D., "Universities should resist calls to 'decolonise the curriculum”, The Spectator, 18 February 2019.

Sunter, A., "TWAIL as Naturalized Epistemological Inquiry", Canadian Journal of Law and Jurisprudence 2007 (20(2)), 475-510.

Tafere, Y. and Pankhurst, A., "Can children in Ethiopian communities combine schooling with work?”, Working Paper 141 (Oxford: Young Lives 2015).

Trandis, H., Bontempo, R., Villareal, M., Asai, M. and Lucca, N., "Individualism and collectivism: cross cultural perspectives on self-ingroup relationships", Journal of Personality and Social Psychology, 1988 (54), 323-338.

Tuck, E. and Yang, K., "Decolonization is not a metaphor”, Decolonization: Indigeniety, Education and Society 2012 (1(1)), 1-40.

Van Beuren, G., "Children's Rights" in Moeckli, D., Shah, S. and Sivakumaran, S., (eds.), International Human Rights Law (Oxford University Press, Oxford, 2018).

Vigneswaran, D., "'Methodological Debates' in Human Rights Research" in Quirk, J. and Bunting, A. (ed.), Contemporary Slavery; Popular Rhetoric and Political Practice (UBC Press, 2017).

Viljoen, F., "Why South Africa Should Ratify the ACRWC', South Africa Law Journal 1991 (11(6)) 66o-664.

Waldron, J., "One Law for All? The Logic of Cultural Accommodation", Washington \& Lee Law Review 2002 (59) 3-35.

Woldehanna, T. and Gebremedhin, A., "Is child work detrimental to the educational achievements of children?" (Oxford: Young Lives, 2015).

Zechenter, E., "In The Name of Culture: Culture Relativism and the Abuse of the Individual", Journal of Anthropological Research 1997 (53 (3)), 319-347. 